\title{
The role of transthoracal echocardiography in closing secundum atrial septal defects with Amplatzer Septal Occluder
}

\author{
Ganesja M Harimurti, Muhamad Munawar
}

\begin{abstract}
Abstrak
Ekokardiografi transesofageal (TEE) dalam anestesi umum telah merupakan prosedur rutin untuk memandu penutupan defek septum atrium tipe sekundum (ASDs) dengan Amplatzer septal occluder (ASO) bersama-sama dengan fluoroskopi dilaboratorium kateterisasi jantung. Untuk menyederhanakan prosedur dan juga untuk mengurangi biaya, telah dipakai ekokardiografi transtorakal (TTE) untuk memandu implantasi ASO. Tujuan studi ini adalah mengevaluasi akurasi dan hasil procedure ASO yang dipandu dengan TTE dibandingkan dengan yang dipandu dengan TEE. Ini merupakan studi komparasi. Sembilan puluh satu penderita dengan ASDs yang telah dicoba untuk penutupan dengan ASO secara transkateter di Rumah Sakit Jantung dan Pembuluh Darah Harapan Kita Jakarta dievaluasi. Akhir-akhir ini, pada 22 penderita, prosedur dilakukan tidak dengan panduan TEE tetapi dengan TTE. Seleksi penderita dilakukan seperti lazimnya dengan TEE dipoliklinik. Diameter dengan balon dilatasi diukur secara TEE atau TTE dan fluoroskopi dilaboratorium kateterisasi jantung. Penderita dibagi atas 2 kelompok, kelompok TEE adalah kelompok yang prosedur dipandu TEE, sedang kelompok TTE adalah yang dipandu TTE. Kasus yang dapat dianalisa sejumlah 83 penderita, 61 kelompok TEE dan 22 kelompok TTE. Pengukuran diameter dengan TTE maupun TEE memiliki korelasi yang tinggi dengan ukuran secara fluoroskopi (masing-masing: $r=0.837$ and $r=0.853$ ). Dan tidak ada perbedaan bermakna antara akurasi pengukuran dengan TEE maupun dengan TTE $(p=0.085)$ dibandingkan dengan ukuran secara fluoroskopi. Waktu fluoroskopi pada prosedur ASO dengan panduan TEE lebih panjang secara bermakna dibanding dengan waktu fluoroskopi dengan panduan TTE (33.2 \pm 21.3 mnt vs. $22.8 \pm 19.3$ mnt, $P=0.014$ ). Selain itu, juga tidak diketemukan perbedaan bermakna pada angka kegagalan antara tehnik panduan TEE maupun TTE. Prosedur ASO dengan panduan TTE mempunyai derajat akurasi yang sama dengan prosedur yang dipandu TEE, dengan waktu fluoroskopi yang lebih singkat. Angka kegagalan dengan panduan TTE juga tidak berbeda dengan yang dipandu TEE. (Med J Indones 2007; 16:14-8)
\end{abstract}

\begin{abstract}
Transesophageal echocardiography (TEE) under general anesthesia has become a routine procedure as guidance in implanting Amplatzer septal occluder (ASO) for closing secundum atrial septal defects (ASDs) together with fluoroscopy in cardiac catheterization laboratory. To simplify the procedure and reduce the cost, recently we used transthoracal echocardiography (TTE) in guiding the ASO implantation. Aim of this study is to evaluate accuracy and performance of ASO procedure guided by TTE compared to ASO procedure guided by TEE. This is a comparative study. Ninety-one patients with ASDs referred for transcatheter closure with ASO in National Cardiovascular Center Harapan Kita Hospital Jakarta were reviewed. In the 22 patients, TTE were used as guidance instead of TEE. Patients selection were performed in the outpatient clinic by TEE. The stretched diameter was measured by TEE or TTE and fluoroscopy. Patients were divided into two groups, TEE group consisted of procedures guided by TEE, and TTE group guided by TTE. From 91 patients, 83 can be evaluated. It consisted of 61 patients in TEE group and 22 in TTE group. Measurement of defects sizes with TTE and TEE have a high correlation with fluoroscopic measurements ( $r=0.837$ and $r=0.853$, respectively). There were no significant differences between the accuracy of TTE and TEE sizes measurement ( $p=0.085)$ compared to fluoroscopy. Fluoroscopy time in ASO procedures guided by TEE was significantly longer than those guided by TTE (33.2 \pm 21.3 min vs. $22.8 \pm 19.3 \mathrm{~min}, P=0.014)$. There was also no significant differences in the failure of devices implantation between TEE and TTE guidance. All patients were in good condition at follow-up. ASO procedures guided by TTE have similar accuracy to those guided by TEE, with shorter fluoroscopy time. TTE guidance also has no difference in failure rate compared to TEE guidance. (Med J Indones 2007; 16:14-8)
\end{abstract}

Keywords: amplatzer septal occluder, secundum atrial septal defect, transthoral echocardiography

Atrial septal defect (ASD) can be found in $5-10 \%$ of all congenital heart disease (CHD), ${ }^{1}$ and they present

Department of Cardiology and Vascular Medicine University of Indonesia, National Cardiovascular Center Harapan Kita, Jakarta, Indonesia later in life. ${ }^{2,3}$ It occurs in women 2-3 times as often in men. ${ }^{4}$ The secundum type atrial septal defect (ASDs) is the most common with an incidence of 3.78 per 10,000 live births, ${ }^{5}$ corresponding to $5.9 \%$ of diagnosed CHDs in children. ${ }^{6}$ For several decades, these defects have either been repaired surgically or treated medically. 
The development of devices for transcatheter closure of ASD represents an important advance in catheterbased management of congenital heart defects. A variety of devices has been developed over the past decades. The Amplatzer septal occluder (ASO) (AGA Medical Cooperation, Golden Valley, Minnesota, USA) is a selfcentering, self-expanding double-disc device (Fig. 1) made of 0.004-0.0075 Nitinol wire mesh (55\% nickel and $45 \%$ titanium), effective for closing ASDs. ${ }^{7-11}$

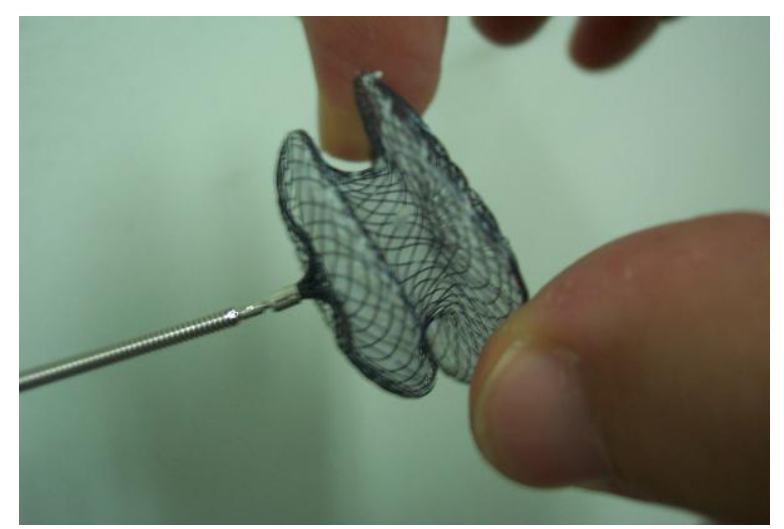

Figure 1. An Amplatzer septal occluder, a double disc nitinol-wire mesh connected by a waist that corresponds to the size of the defect.

Transcatheter closure of secundum atrial septal defect (ASDs) with Amplatzer septal occluder (ASO) has been an alternative intervention to surgery. More and more patients chose this procedure due to several reasons such as no surgical scar, short duration of hospital stay which is only 2 nights. The procedure is performed in the cardiac catheterization laboratory under general anesthesia, using transesophageal echocardiography (TEE) as guidance. TEE has become a routine procedure as guidance and monitoring proper device placement during transcatheter closure of ASDs. ${ }^{7,8,12-14}$

To simplify the procedure and to reduce the cost, recently we used transthoracal echocardiography (TTE) in guiding the ASO implantation in some patients. Not using general anesthesia resulted in reduced cost of 750,000 rupiahs. Aim of this study is to evaluate accuracy and performance of ASO procedure guided by TTE compared to ASO procedure guided by TEE.

\section{METHODS}

We evaluated all transcatheter closure of ASDs with ASO that have been attempted in the Cardiac Catheterization
Laboratory of National Cardiovascular Center Harapan Kita, Jakarta, from September 2002 to July 2006. All procedures guided by TEE were performed under general anesthesia, while in those guided by TTE, they were fully awake, except in small children where sedatives were given. Indication of closing ASDs is the same as for surgery, inclusion criteria were single ASDs, significant left to right shunt, superior rim of at least $5 \mathrm{~mm}$, the defect had to be at least $5 \mathrm{~mm}$ away from coronary sinus, atrio-ventricular valves, and right pulmonary vein. Exclusion criteria were multiple ASD, insufficient superior rim, pulmonary vascular disease, associated $\mathrm{CHD}$ requiring surgery, partial anomalous of pulmonary vein drainage, congestive heart failure with ejection fraction $<30 \%$. Selection of cases were performed in outpatient clinics with TEE; in small children, the procedures were performed in the one day care ward. Children with body weight less than $20 \mathrm{~kg}$ and size of defect more than $20 \mathrm{~mm}$ were sent to surgery.

In TTE procedure, we used transthoracal 4-chamber view to visualize the atrial septum in vertical position. When the sizing balloon was inflated for defect diameter sizing, it was in horizontal position in the atrial septum (Fig. 2). In this view we could visualize the guiding catheter going through the defect. When the devices were in the left atrium with the left sided part deployed, the devices position were aligned with the atrial septum (Fig. 3), so we were fully guided by the picture. Then we continued with deploying the right atrial disc (Fig. 4). If from the TTE the position of the device was correctly adjusted to the defect, the device was released from the cable. Sizes of defects measured that were evaluated in this study were stretched diameters measured by TEE or TTE and fluoroscopy with balloon sizing.

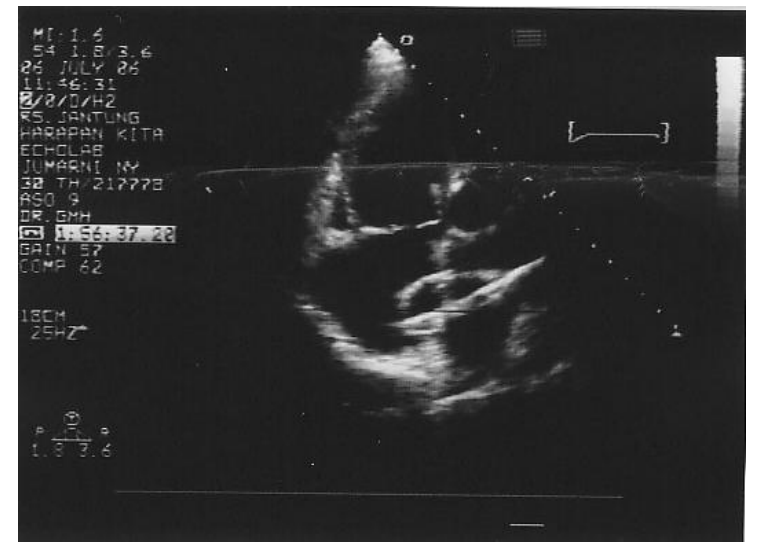

Figure 2. TTE image from transthoracal 4-chamber view measuring the balloon stretched diameter of ASD. RA:right atrium, LA: left atrium, $R V$ :right ventricle 


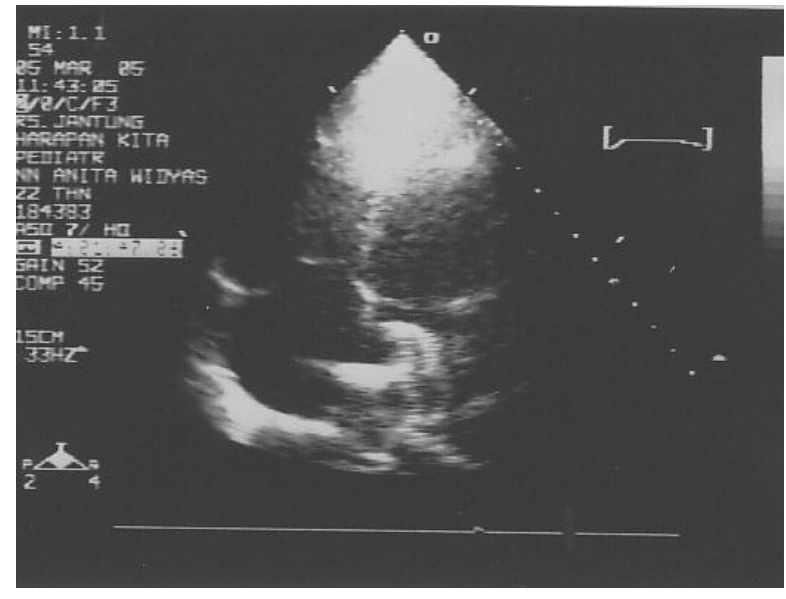

Figure 3. TTE image showing the left atrial ASO disc deployed in left atrium while the right atrial disc still in the delivery sheath.

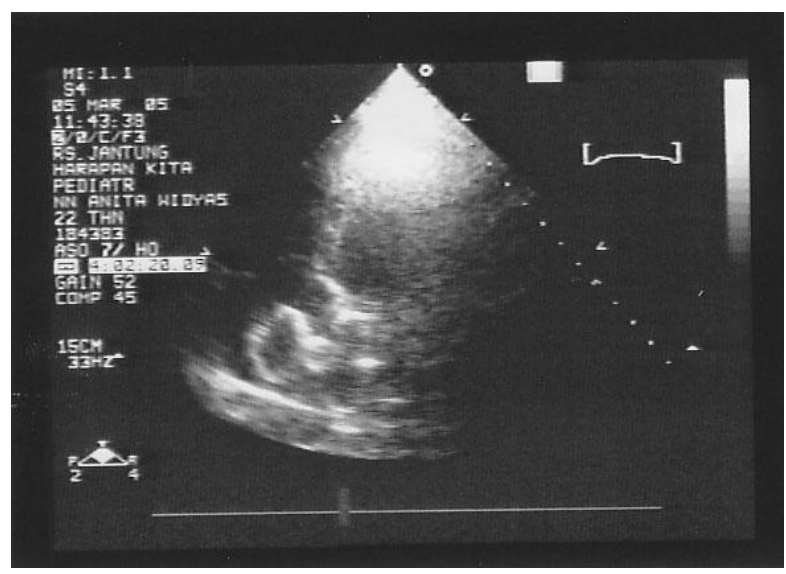

Figure 4. TTE image demonstrating both disc already deployed.

Data was presented in count (percentage) for nominal variables or in mean \pm standard deviation for continuous variables. To evaluate accuracy of TTE guidance and TEE guidance, we did non-parametric Spearman's correlation analysis between defect size measured using echocardiography (TTE or TEE) and defect size measured using fluoroscopy. To compare between both guidance, we evaluated the differences in size measurement of TTE or TEE and size of fluoroscopy using Mann-Whitney test. We also evaluated performance of ASO procedure guided by TTE or TEE by comparing failure and complication rate of both groups. $\mathrm{P}$ value of less than 0.05 is considered significant statistically. All statistical analysis was done using SPSS 13.0 (SPSS Inc.)

\section{RESULTS}

From September 2002 to July 2006, transcatheter closure of ASDs with ASO has been attempted in 91 cases, and in $81(89 \%)$ cases implantation were successful. Group TEE consisted of 69 patients which used TEE as guidance, group TTE consisted of 22 cases with TTE. From 91 cases, 8 cases data were not complete. From 83 cases evaluated, 61 were in group TEE and 22 in group TTE.

There was no significant difference in overall baseline characteristics between both groups (Table 1). Mean age of patients undergoing ASO procedure was $25 \pm$ 15 years; most $(70 \%)$ were female.

There were also no difference in diameter measured by fluoroscopy and size of ASO used between both group. In overall ASO procedures, size of occluder devices used range from 12 to $38 \mathrm{~mm}$ (mean $26.1 \pm 6.4 \mathrm{~mm}$ ).

There was high correlation in diameter between TTE and fluoroscopy $(\mathrm{r}=0.837, \mathrm{p}<0.001)$, and between TEE and fluoroscopy diameter $(r=0.853, p<0.001)$. We found no significant difference in difference of size by echo and size by fluoroscopy between both TTE and TEE group $(0.5 \pm 3.8$ and $2.0 \pm 3.5$, respectively, $\mathrm{P}=0.072$ ). Fluoroscopy time in ASO procedures guided by TEE was longer compared to those guided by TTE, and the difference is statistically significant (33.2 \pm 21.3 min vs. $22.8 \pm 19.3 \mathrm{~min}, \mathrm{P}=0.014$ ).

Table 1. Baseline characteristics of study population

\begin{tabular}{lccc}
\hline & $\begin{array}{c}\text { TTE } \\
(\mathrm{n}=22)\end{array}$ & $\begin{array}{c}\text { TEE } \\
(\mathrm{n}=61)\end{array}$ & $\begin{array}{c}\mathrm{P} \\
\text { value }\end{array}$ \\
\hline Female & $16(72.7 \%)$ & $42(68.9 \%)$ & 0.766 \\
Age, years & $24.7 \pm 15.2$ & $25.5 \pm 15.0$ & 0.905 \\
Weight, kg & $43.4 \pm 20.2$ & $46.8 \pm 19.6$ & 0.528 \\
$\begin{array}{l}\text { Height, cm } \\
\text { Diameter (echo- }\end{array}$ & $146.6 \pm 23.1$ & $148.2 \pm 21.3$ & 0.751 \\
$\quad$ cardiography), mm & $23.3 \pm 6.6$ & $21.0 \pm 6.4$ & 0.243 \\
$\begin{array}{c}\text { Diameter (fluoros- } \\
\quad \text { copy), mm }\end{array}$ & $23.8 \pm 6.6$ & $23.0 \pm 6.3$ & 0.605 \\
$\quad$ ASO size, mm & $26.6 \pm 7.4$ & $25.8 \pm 6.1$ & 0.667 \\
\hline
\end{tabular}

Data were presented as count (percentage) or mean \pm standard deviation

In group TEE, failure in implantation of devices occurred in 10 cases $(16.1 \%)$, while in group TTE failure in 2 $(9.1 \%)$ (Table 2), there is no significant difference $(\mathrm{p}=0.418)$. Atrial fibrillation occurred in one case in 
group TEE. This patient in fact has thyroid disease. Migration of devices occurred in 2 cases in TEE group. Total atrioventricular block occurred in 3 cases in TEE group and In 1 case in TTE group. In the case which total AV block occurred in the TTE group, the size of defect is also very large. In TEE group, immediate closure occurred in 50 cases $(82 \%)$, complete closure from evaluation the next day in 94\%), while in TTE group, immediate closure in 18 cases $(90 \%)$, complete closure the next day in $100 \%$ cases. All patients were discharged the next day, aspirin were given for six months.

Table 2. Failure rate and complication in ASO procedure guided by TTE and TEE

\begin{tabular}{lccc}
\hline & TTE & TEE & P \\
& $(\mathrm{n}=22)$ & $(\mathrm{n}=61)$ & value \\
\hline Fail, due to: & $2(9.1 \%)$ & $10(16.1 \%)$ & 0.418 \\
1. failure of implantation & 0 & 3 & \\
2. too large defect & 1 & 2 & \\
3. ASO migration & 0 & 2 & \\
4. Total AV Block & 1 & 3 & \\
\hline Complication: & & & \\
1. AF & 0 & 1 & \\
\hline
\end{tabular}

\section{DISCUSSION}

Transcatheter closure of secundum atrial septal defects with ASO has been approved by FDA since December 2001. Since then this procedure has been performed in many centers, can be repositioned and retrieved prior to its release, and has a high rate of complete closure.

If performed in children, surgical closure of ASDs results in reduction of right ventricle volume overload and normalization of the size, ${ }^{15}$ and similar results were also encountered if the defects were closed transcatheter with ASO. ${ }^{16}$

TEE provides high accuracy in measuring the size of defects and assessing the type of defects, and also for showing the adequacy of the septal rims. A minimum of $5 \mathrm{~mm}$ of superior anterior rim is required for stable positioning of the device, while the aortic side rim is not mandatory due to the ability of the device to straddle the aorta. But TEE as guidance is uncomfortable for the patient, because it requires general anesthesia, may give limited views of the left atrium, and requires an additional expert operator ${ }^{17}$ with additional cost.
In 22 patients in our study, we used TTE as guidance. The window used is transthoracal 4-chamber view visualizing atrial septal in vertical position. We are more familiar with this view as we used this daily in practice for diagnostic, and there is no limited views of the left atrium. There is no need for expert operator, and more cost effective. We can visualized clearly the introducer sheath loaded with ASO device entered left atrium from right atrium, then we can visualized when the left atrial side disc was deployed in the left atrium continued with deploying the right atrial disc in right atrium.

There were no significant differences in the characteristics between the 2 groups. Comparing the size diameter found between TTE and fluoroscopy, there were no difference, $23.3 \pm 6.6 \mathrm{~mm}$ and $23.8 \pm 6.6 \mathrm{~mm}$ respectively. Also between size diameter found by TEE and fluoroscopy, $21.0 \pm 6.4 \mathrm{~mm}$ and $23.0 \pm 6.3$ $\mathrm{mm}$ respectively. We found no difference in accuracy of both echo guidance compare to fluoroscopy. These results reflects that TTE guidance have the same accuracy as TEE guidance, which have been used as routine procedures previously, and the fluoroscopy time in ASO procedures guided by TTE was shorter significantly compared to those guided by TEE. Sizes of devices chosen were equal or usually $2 \mathrm{~mm}$ larger than the sizes from balloon sizing. It is interesting to observe in our study that in TTE group, the size of devices chosen were close to both sizes measured by TTE and fluoroscopy, but in TEE group, the size of devices chosen were closer to size measured by fluoroscopy than by TEE. There was no significant difference between the failure of implantation between those two groups.

TTE guidance is still a new technique for ASO procedure, resulted in small sample size in TTE group compared to TEE group. It is, in fact, a goal of this study to motivate an increase in learning curve of TTE guidance for ASO procedure.

\section{CONCLUSION}

ASO procedures guided by TTE have similar accuracy to those guided by TEE, with shorter fluoroscopy time. TTE guidance also has no difference in failure rate compared to TEE guidance. TTE can be used safely and successfully as guidance in closing ASDs with ASO. This procedure is more friendly for the patients and relatively cost effective because general anesthesia is not required. Also more friendly for the users because the window used were more familiar. 


\section{Acknowledgment}

The authors thank Prof. dr. Bastaman Basuki for his assistance.

\section{REFERENCES}

1. Hales WD, Sandhu SK, Kerut EK. The Amplatzer septal occluder as a standard for therapy of secundum-type atrial septal defect (abstr). J La State Med Soc. 2004; 156:99-100.

2. Seldon WA, Rubenstein C, Fraser AA. Incidence of atrial septal defect in adults. Br Heart J. 1962;24:557-60.

3. Rostad H, Sorland SJ. Atrial septal defects of secundum in patients less than 40 years of age: a follow-up study. Acta Medica Scand. 1981;Suppl 645:29-35.

4. Campbell M. Natural history of atrial septal defect. $\mathrm{Br}$ Heart J. 1970;32:820-6.

5. Emmanoulides GC, Allen HD, Reinmenschneider TA et al. Heart Diseases in Infants and Young Adults. In: Clark EB, Gutgesell HP, eds. Baltimore: Williams and Wilkins; 1995.p.60-9.

6. Dickinson DE, Arnold R, Wilkinson JL. Congenital heart disease among 160480 liveborn children in Liverpool 1960 to 1969. Implications for surgical treatment. $\mathrm{Br}$ Heart J. 1981;46:55-62.

7. Masura J, Gavora P, Formanek A, Hijazi ZM. Transcatheter closure of secundum atrial septal defects using the new self-centering amplatzer septal occluder: initial human experience. Cathet Cardiovasc Diagn. 1997;42:388-93.

8. Berger F, Ewert P, Bjornstad PG, Dahnert I, Krings G, Brilla-Austenat I, Vogel M, Lange PE. Transcatheter closure as standard treatment for most interatrial defects: experience in 200 patients treated with the Amplatzer Septal Occluder. Cardiol Young. 1999;9:468-73.
9. Fischer G, Kramer HH, Stieh J, Harding P, Jung O. Transcatheter closure of secundum atrial septal defects with the new self-centering Amplatzer Septal Occluder. Eur Heart J. 1999;20:541-9.

10. Chan KG, Godman MJ, Walsh K, Wilson N, Redington A, Gibbs JL. Transcatheter closure of atrial septal defect and interatrial communications with a new self-expanding nitinol double disc device (Amplatzer septal occluder): multicenter UK experience. Heart. 1999;82:300-6.

11. Harimurti GM. Transcatheter Closure of Secundum Atrial Septal Defect. Presented in $15^{\text {th }}$ Asean Conggress of Cardiology. Pataya, Thailand Oct 2004.

12. Hellenbrand WE, Fahey JT, McGowen FX, Weltin GG, Kleinman CS. Transesophageal echocardiographic guidance of transcatheter closure of atrial septal defect. Am J Cardiol. 1990;66:207-13.

13. Tseng HC, Hsiao PN, Lin YH, Wang JK, Tsai SK. Transesophageal echocardiographic monitoring for transcatheter closure of atrial septal defect. J Formos Med Assoc. 2000;99:684-8.

14. Chen CY, Lee CH, Yang MW, Chung HT, Hsieh IC, Ho ACY. Usefulness of transesophageal echocardiography for transcatheter closure of ostium secundum atrial septum defect with the Amplatzer septal occluder. Chang Gung Med J. 2005;28:837-45.

15. Pearlman AS, Borer JS, Clark CE, Henry WL, Redwood DR, Morrow AG, Epstein SE. Abnormal right ventricular size and ventricular septal motion after atrial septal defect closure: etiology and functional significance. Am J Cardiol. 1978;41:295-301.

16. Yew G, Wilson NJ. Transcatheter atrial septal defect closure with the Amplatzer septal occluder: five-year follow-up. Catheter Cardiovasc Interv. 2005;64:193-6.

17. Mullen MJ, Dias BF, Walker F. Intracardiac echocardiography guided device closure of atrial septal defects. J Am Coll Cardiol. 2003;41:285-92. 
